\title{
Reinforcing and expanding the predictions of the disturbance vicariance hypothesis in Amazonian harlequin frogs: a molecular phylogenetic and climate envelope modelling approach
}

\author{
Stefan Lötters • Arie van der Meijden • Dennis Rödder • \\ Timo E. Köster • Tanja Kraus • Enrique La Marca • \\ Célio F. B. Haddad • Michael Veith
}

Received: 7 August 2008/Accepted: 19 February 2010/Published online: 6 June 2010 (C) The Author(s) 2010. This article is published with open access at Springerlink.com

\begin{abstract}
The disturbance vicariance hypothesis (DV) has been proposed to explain speciation in Amazonia, especially its edge regions, e.g. in eastern Guiana Shield harlequin frogs (Atelopus) which are suggested to have derived from a cool-adapted Andean ancestor. In concordance with DV predictions we studied that (i) these amphibians display a natural distribution gap in central Amazonia; (ii) east of this gap they constitute a monophyletic lineage which is nested within a pre-Andean/western clade; (iii) climate envelopes of Atelopus west and east of the distribution gap show some macroclimatic divergence due to a regional climate envelope shift; (iv) geographic distributions of climate envelopes of western
\end{abstract}

S. Lötters $(\bowtie) \cdot$ A. van der Meijden · D. Rödder · M. Veith

Department of Biogeography, Trier University, 54286 Trier, Germany

e-mail: loetters@uni-trier.de

A. van der Meijden

e-mail: frog@arievandermeijden.nl

D. Rödder

e-mail: roedder@uni-trier.de

M. Veith

e-mail: veith@uni-trier.de

S. Lötters · A. van der Meijden - M. Veith

Institute for Biodiversity and Ecosystem Dynamics, University of Amsterdam, Kruislaan 318, 1098 SM Amsterdam, The Netherlands

A. van der Meijden

CIBIO, Centro de Investigação em Biodiversidade e Recursos Genéticos, Campus Agrário de Vairão, 4485-661 Vairão, Portugal

T. E. Köster

Department of Zoology, University of Mainz, Saarstrasse 21, 55099 Mainz, Germany

e-mail: koestert@students.uni-mainz.de

T. Kraus

German Remote Sensing Data Center, German Aerospace Center (DLR), P.O. Box 1116, 82230 Wessling, Germany

e-mail: tanja.kraus@dlr.de 
and eastern Atelopus range into central Amazonia but with limited spatial overlap. We tested if presence and apparent absence data points of Atelopus were homogenously distributed with Ripley's K function. A molecular phylogeny (mitochondrial 16S rRNA gene) was reconstructed using Maximum Likelihood and Bayesian Inference to study if Guianan Atelopus constitute a clade nested within a larger genus phylogeny. We focused on climate envelope divergence and geographic distribution by computing climatic envelope models with MaxEnt based on macroscale bioclimatic parameters and testing them by using Schoener's index and modified Hellinger distance. We corroborated existing DV predictions and, for the first time, formulated new DV predictions aiming on species' climate envelope change. Our results suggest that cool-adapted Andean Atelopus ancestors had dispersed into the Amazon basin and further onto the eastern Guiana Shield where, under warm conditions, they were forced to change climate envelopes.

Keywords Atelopus - Bayesian inference - Bioclimate $\cdot$ MaxEnt $\cdot$ Maximum likelihood · Ripley's K function · South America

\section{Abbreviations \\ AUC Area under the receiver operating characteristic curve \\ DV Disturbance vicariance hypothesis}

\section{Introduction}

There is a lot of ongoing debate regarding the explanation of plant and animal diversification in the Amazon basin and adjacent Guianas. Several historical biogeographic scenarios have been suggested (e.g. Haffer 1997, 2008; Hall and Harvey 2002; Noonan and Wray 2006). This paper focuses on the disturbance vicariance hypothesis (DV), which is described by Bush (1994), Noonan and Gaucher (2005) and Haffer (2008) derived from pollen analyses and patterns of species phylogenies. DV explains incomplete speciation in taxa on the eastern Guiana Shield due to relatively short phases of climate change during Pleistocene. During interglacials, cool-adapted species were retracted to higher elevations and allopatric speciation started, a process which was interrupted ('disturbed') as renewed glacials allowed for secondary contact via lowlands. Such a scenario, for instance, is suggested for caesalpinioid trees (Dutech et al. 2003) or bufonid and dendrobatid frogs (Noonan and Gaucher 2005, 2006). According to Bush (1994) and Noonan and Gaucher (2005), cool-adapted Guiana Shield taxa, which have undergone DV, are of Andean origin. This needs further explanation. Since Cenozoic, repeated phases of cool climate forced plant and animal taxa from the eastern Andean versant to occupy altitudinal ranges several

\footnotetext{
E. La Marca

Laboratorio de Biogeografía, Escuela de Geografía, Facultad de Ciencias Forestales y Ambientales, Universidad de Los Andes, Apartado Postal 116, Merida 5101-A, Venezuela e-mail: enrique.lamarca@gmail.com

C. F. B. Haddad

Departamento de Zoologia, Instituto de Biociências, Universidade Estadual Paulista, Rio Claro, CEP 13506-900, Caixa Postal 199, Rio Claro, SP, Brazil

e-mail: haddad1000@gmail.com
} 
hundred meters lower. Accordingly, diversity in the Amazon lowlands of coffee (Rubiaceae) or poison frogs (Dendrobatoidea) is explained, to give two examples recently studied (Antonelli et al. 2009; Santos et al. 2008). However, for a long time, eastward dispersal onto the eastern Guiana Shield was impossible as a result of marine incursions from the Caribbean Sea into western Amazonia (Lake Pebas). With further uplift of the Andes, this incursion vanished around the change from mid to late Miocene, 11-7 mya (e.g. Antonelli et al. 2009) and the Amazon River was born (Hoorn 2006). In the subsequent late Miocene climate, 5.4-9 mya (i.e. the South American Huayquerian), the Amazon has already entrenched to its today's bed (Figueiredo et al. 2009). The climate was cooler than that of the current postglacial (i.e. Holocene) but not as cool as during glacial periods, allowing for extensive forest cover over Amazonia (Bush 1994). Only during this time span, cooladapted Andean forest species were able to reach the eastern Guiana Shield (Fig. 1a). With warming during the subsequent Pliocene forest cover persisted, but persistence or dispersal of cool-adapted species would have been impossible (Bush 1994). Cool-adapted species in western Amazonia could easily respond to warming by restriction to higher elevations along the Andean versant. Likewise on the eastern Guiana Shield, cool-adapted species were retracted to the numerous existing hills. Vicariant speciation processes were thus initialized (Fig. 1b). With every Pleistocene glacial (starting only ca. 500,000 years BP), this retraction was 'disturbed' as renewed cooling allowed for lowland dispersal, as mentioned above (Fig. 1c-d). New dispersal from western Amazonia or re-dispersal from the eastern Guiana Shield deep into central Amazonia was impossible, as glacial cooling was stronger than that during the late Miocene accompanied by a reduction in precipitation of up to 20\% (Bush 1994). As proposed further by Bush (1994), this resulted in forest loss leaving lowland forest fragments in western Amazonia along the Andean versant and on the eastern Guiana Shield plus vicinities only (Fig. 1c).

Harlequin frogs (Atelopus) are a species-rich bufonid genus of Andean origin, with more than 100 species occurring in forest or paramo habitats in the Andes (Lötters 1996; La Marca et al. 2005). In this paper we focus on the less than 10 Atelopus (depending on the taxonomy applied; see Lötters et al. 2002) occurring exclusively in forest habitats in the Amazon basin and on the eastern Guiana Shield. In an earlier molecular genetic study, Noonan and Gaucher (2005) showed that the five nominal species of the eastern Guiana Shield harlequin frogs are genetically little differentiated and that they apparently interbreed in nature. Supported by divergence time estimates, these authors advocated that the observed phylogeographical patterns in Atelopus fit DV predictions, i.e. that a single Andean ancestor had invaded the eastern Guiana Shield (likely in late Miocene, as also suggested for other anuran amphibians; Santos et al. 2008) and has started speciation there in the Pleistocene due to the alteration of glacial and interglacial phases (as illustrated in Fig. 1a-d).

To their molecular phylogeny, Noonan and Gaucher (2005) added only four Atelopus species from outside the eastern Guiana Shield. As a result, the validity of their study is pending on additional corroboration. This is especially significant because our knowledge on the current distribution of harlequin frogs in central Amazonia is poorly understood. Lescure and Gasc (1986), with providing data, proposed a continuous distribution of harlequin frogs from the Andes to the eastern Guiana Shield. In contrast, Lötters et al. (2002), in a taxonomic study, were unable to trace Atelopus material in scientific collections from a large part of central Amazonia, casting some doubt on a continuous distribution. Such a hiatus could be well explained by DV predictions, since the recolonisation of central Amazonia, either from the western Amazonian lowlands or from the eastern Guiana Shield plus vicinities, would be impossible during the current postglacial. From a 

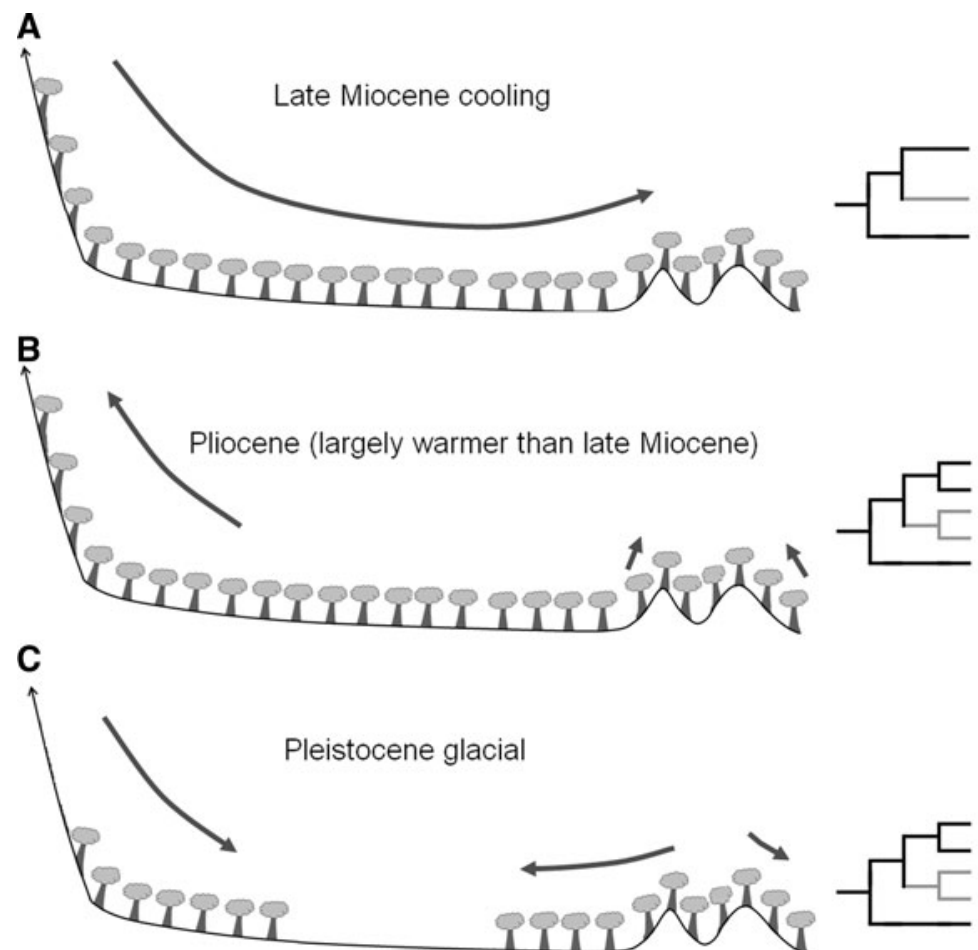

Pleistocene glacial

D

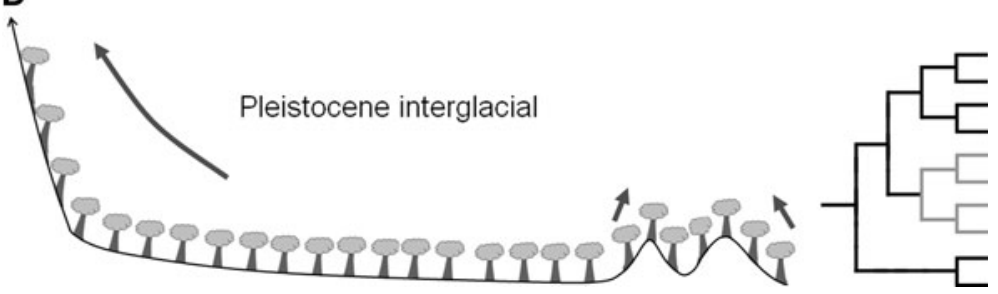

Fig. 1 Schematic illustration of DV with Andes in the West (left) and the eastern Guiana Shield in the East (Guiana Shield species indicated in grey in phylogenetic trees): (a) cooling during the late Miocene allowed for dispersal (arrow in drawing, grey in phylogenetic tree) of cool-adapted forest taxa from the Andean versant eastward up to the eastern Guiana Shield; (b) due to subsequent warming (Pliocene) cool-adapted species were retracted to higher elevations (arrows) resulting in vicariant speciation; (c) speciation is 'disturbed' during Pleistocene glacials cool-adapted species as lowland dispersal was possible again (with limitations due to forest loss and the development of a western and an eastern forest fragment); (d) retraction to higher elevations and speciation continued during warmer interglacials. Scenario (d) was followed by (c) for several times. Scheme not to scale

phylogenetic point of view, according to DV predictions and the findings of Noonan and Gaucher (2005), we expect that harlequin frogs from east of this suspected distribution gap in central Amazonia constitute one clade nested within those from the Andes and Amazonian lowlands adjacent to them (Fig. 1d) if more species were included from more of the genus' entire geographic range than available to Noonan and Gaucher (2005).

Species can respond to climate change in two ways. One is change of geographic range (i.e. increase, decrease down to extinction, shift) and maintenance of the specific climate envelope, termed niche conservancy (e.g. Peterson et al. 1999; Wiens and Graham 2005). 
In the other the geographical range is retained, necessarily accompanied by climate envelope shift (e.g. Broennimann et al. 2007; Pearman et al. 2007; Rödder et al. 2009). Species climate envelope predictions have never been formulated with regard to DV. According to our understanding of DV, we largely expect climate conservancy in Amazonian and Guianan Atelopus as, under DV, species change their geographic ranges as a response to a changing climate (Fig. 1a-d). Vertical range shift of cool-adapted species along the Andean versant was up to $800 \mathrm{~m}$ (Bush 1994). However, maximum altitudes found on the eastern Guiana Shield have been about $300 \mathrm{~m}$ above today's sea level only. As niche shift is facilitated in small populations pushed to their margin of environmental tolerance (Holt and Gomulkiewicz 2004; Holt et al. 2005; Jakob et al. 2010), it may be assumed that within the eastern glacial forest fragment (Fig. 1c) climate envelopes have shifted in those cool-adapted species which have survived warmer periods. As a consequence, when comparing current-day Atelopus populations from the western and eastern Amazonian (including the eastern Guiana Shield) lowlands (Fig. 1c) their climate envelopes under today's macroclimate are predicted to show some divergence.

The contemporary postglacial was warmest about 8,000-4,500 years BP and temperature has decreased since then. According to DV, harlequin frog species should currently be able to re-expand their distributions into lower areas. When mapping climate envelopes of current-day Atelopus populations from both western and eastern Amazonia under macroclimatic conditions into geographic space, they should range into central Amazonia. However, because of the expected climate envelope shift in eastern Amazonian Atelopus, mapped climate envelopes (which can be understood as species' potential distributions) are predicted to be rather allopatric than sympatric.

In this paper we combined different methodological approaches to study (i) if extant harlequin frogs display a central Amazonian distribution gap; (ii) if eastern Amazonian Atelopus constitute a single clade nested in a phylogeny comprising an enlarged data set from the Andes and adjacent lowlands; (iii) if climate envelopes of western versus eastern Amazonian populations (i.e., geographically well delimitated by a natural central Amazonian distribution gap) are divergent under today's macroclimate; (iv) if allopatry is the result rather than sympatry when mapping these climate envelopes into geographic space. We discuss in how far our result reinforce and expand DV predictions.

\section{Methods}

\section{A central Amazonian distribution gap}

In order to determine the extant distribution of Atelopus in Amazonia, 87 presence data points from all over Amazonia were employed in this study (Fig. 2). They were taken from published references and obtained through interviews with seven experts (see Appendix). Interviews were open, non-standardized, as described by Atteslander (2008). Only acknowledged experts in anuran taxonomy and with field experience in Amazonia or the eastern Guiana Shield were interviewed. Additional presence data were taken from scientific collections. As an altitudinal limit for pre-Andean/western Amazonia we chose $800 \mathrm{~m}$ above sea level, the approximate upper border of the tierra caliente lowlands. Latitude and longitude coordinates for presence data points were obtained from the sources listed in the Appendix. If not provided, they were obtained through the Alexandria Digital Library Gazetteer (Hill and Zheng 1999; http://www.alexandria.ucsb.edu/gazetteer). 


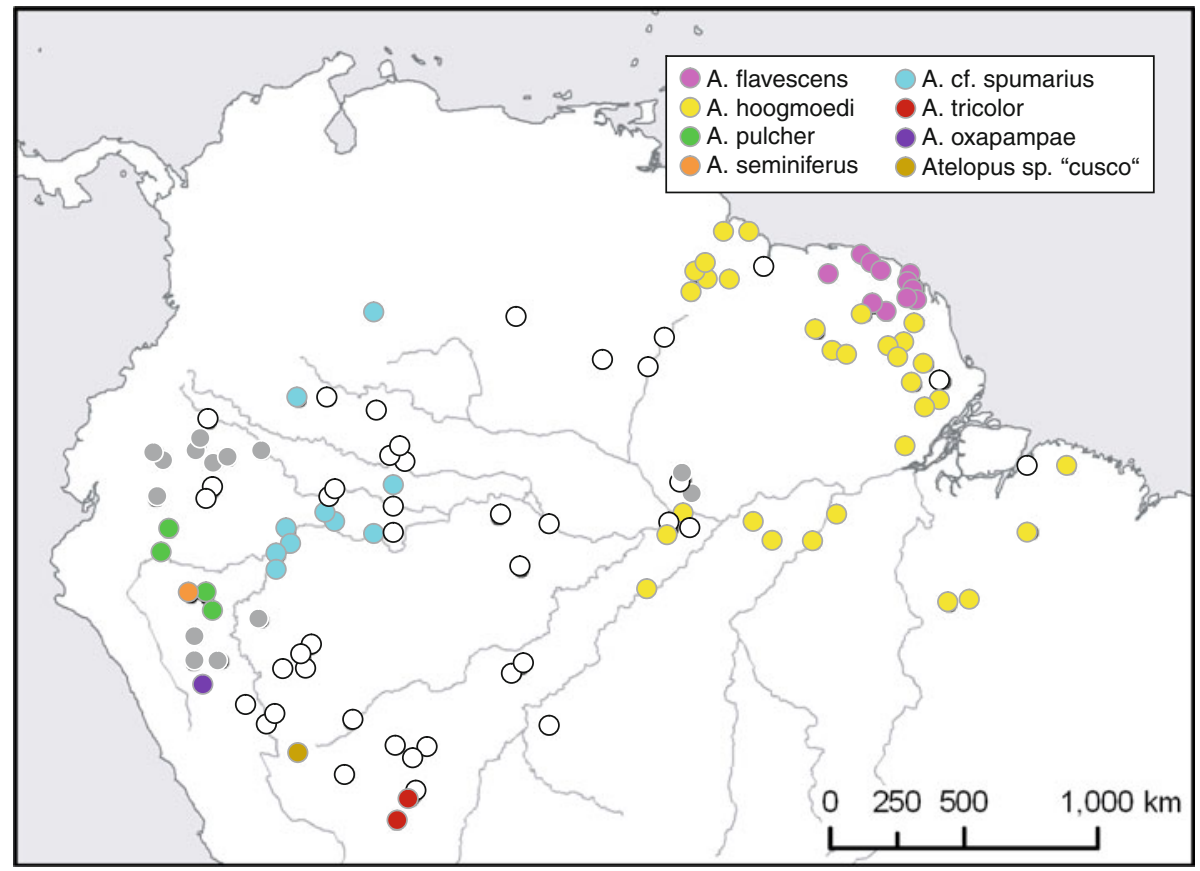

Fig. 2 Northern South America showing data points of presence (grey and coloured circles) and apparent absence (open circles) of harlequin frogs in Amazonia (see Appendix). Colours refer to presence points of Amazonian taxa processed in the phylogeny. (Color figure online)

In addition, 42 data points of apparent absence of harlequin frogs, illustrated in Fig. 2 (see Appendix), were obtained from published references and expert interviews as described above. We only included data points at elevations $\leq 800 \mathrm{~m}$ above sea level and situated in an area defined through a Minimum Convex Polygon (MCP) for all presence data, created with DIVA-GIS 5.4.

We are aware that absence is nearly impossible to prove and should be handled with caution; therefore, we independently analysed presence and absence information. For this, Ripley's K function, a multi-distance spatial cluster analysis, was used to independently study spatial dependence in both data sets (Fig. 2) by comparison to a random pattern, which follows a Poisson distribution (Ripley 1977; Haase 1995). If the K function of the data differs significantly from that of the random distribution, data points under study are clustered (i.e. aggregated, when above that of the random distribution) or highly dispersed (i.e. when below random expectation). Analysis was performed with the Spatial Statistics (confidence envelope: 99 permutations) tool box of ArcGIS Desktop 9.2 (ESRI; http://www.esri.com).

\section{Nested monophyly of eastern Amazonian Atelopus}

Noonan and Gaucher (2005) based their study on fragments of the mitochondrial genes cyt $b$ and ND2. We here chose a fragment of the mitochondrial 16S rRNA gene for two reasons. First, this locus is a widely used marker in amphibian systematics, especially suitable because of strong constancy of priming sites and information content at the species 
Table 1 List of species used for the molecular analysis, their GenBank accession numbers and origin

\begin{tabular}{lll}
\hline Species & Accession number & Locality \\
\hline Atelopus bomolochos & AF375508 & Ecuador: near Zhund \\
Atelopus chiriquiensis & U52780 & Panama \\
Atelopus flavescens & EU672970 & French Guiana: Lac des Americains \\
Atelopus flavescens ('barbotini') & EU672971 & French Guiana: near Saül \\
Atelopus halihelos & AF375510 & Ecuador: near Plan de Milagro \\
Atelopus hoogmoedi & EU672972 & French Guiana: Monts Bakra \\
Atelopus longirostris & AF375511 & Ecuador, Mindo region \\
Atelopus pulcher & EU672973 & Peru: Tarapoto region \\
Atelopus hoogmoedi & EU672974 & Guiana: Mabura Hill region \\
Atelopus hoogmoedi & DQ283260 & French Guiana: near Saül \\
Atelopus spurrelli & EU672975 & Colombia: Bahía Solano \\
Atelopus seminiferus & EU672976 & Peru: Alto Mayo \\
Atelopus cf. spumarius & EU672977 & Peru: Iquitos region \\
Atelopus tricolor & EU672978 & Bolivia: Yungas de La Paz \\
Atelopus varius & U52779 & Panama \\
Atelopus varius & AY325996 & Costa Rica: near Las Alturas \\
Atelopus zeteki & DQ283252 & Panama: Las Filipinas \\
Atelopus oxapampae & EU672979 & Peru: Oxapampa region \\
Atelopus sp. 'cusco' & EU672980 & Peru: near Puente Fortaleza \\
Atelopus sp. 'cocha' & AF375509 & Colombia: Laguna Cocha \\
Rhinella marina & DQ283062 & Peru \\
Dendrophryniscus brevipollicatus & AF375515 & Brazil \\
Osornophryne puruanta & EU672982 & Ecuador \\
Osornophryne antisana & EU6729823 & Ecuador \\
Osornophryne sp. 1 & EU672981 & Ecuador \\
Osornophryne sp. 2 & EU6729824 & Ecuador \\
Eleutherodactylus cf. johnstonei & AF124123 & Unknown \\
\hline & & \\
& & \\
\hline & &
\end{tabular}

level (e.g. Vences et al. 2005). Second, the use of 16 S allowed us to maximize the species sample size in order to study nested monophyly of eastern Amazonian harlequin frogs. As listed in Table 1, sequences of nine Atelopus (three outgroup species) were available from GenBank (http://www.ncbi.nlm.nih.gov; Benson et al. 2004). We supplemented these data by sequencing $16 \mathrm{~S}$ for 11 additional Atelopus plus four outgroup taxa (Table 1).

DNA was extracted from toe clips. Tissue samples (stored in $99 \%$ ethanol) were digested using proteinase $\mathrm{K}$ (final concentration $1 \mathrm{mg} / \mathrm{mL}$ ), homogenised and subsequently purified following a high-salt extraction protocol (Bruford et al. 1992). Polymerase chain reaction (PCR) primers for the fragment of the 16S rRNA gene were 16SA-L and 16SB-H of Palumbi et al. (1991), used as in Van der Meijden et al. (2007). PCR products were purified via spin columns (Qiagen). Sequencing was performed directly using the corresponding PCR primers. New sequences were combined with existing sequences taken from GenBank in the final dataset containing 27 taxa including bufonid and non-bufonid outgroups (Table 1). Sequences were aligned using ClustalW (Thompson et al. 1994) and subsequently edited by hand. The final alignment contained a total of 570 positions of which 219 were variable and 136 were parsimony-informative. 
Phylogeny reconstruction was performed using Maximum Likelihood (ML) and Bayesian Inference (BI) methods. Gaps were treated as unknown characters. The best fitting models of sequence evolution were determined by the AIC criterion as implemented in Modeltest 3.06 (Posada and Crandall 1998). ML tree searches were performed using PhyML, version 2.4.4 (Guindon and Gascuel 2003). Bootstrap branch support values were calculated with 200 replicates. The Bayesian analyses of the combined and separate datasets was conducted with MrBayes 2.0 (Huelsenbeck and Ronquist 2001) with 2 million generations, sampling trees every 10th generation and calculating a consensus tree after omitting the first 200,000 trees as burn-in determined with the Tracer 1.4 (http://beast. bio.ed.ac.uk/Tracer). No well supported topological differences were found between the BI and ML trees; the ML tree was used in the subsequent analysis.

\section{Divergence in climate envelopes and allopatry}

Climate envelopes for western and eastern Amazonian Atelopus were modelled, subsequently mapped into geographic space and compared. For our approach we used the presence data points listed in the Appendix (30 for all western and 54 for all eastern Amazonian Atelopus; Fig. 2). We created models based on seven macroscale bioclimatic parameters (Table 2) describing the availability of thermal energy and water, widely used in climate envelope models (e.g. Carnaval and Moritz 2008; Rödder and Lötters 2009). Using DIVA-GIS 5.4 (Hijmans et al. 2001), bioclimatic parameters were extracted from the WorldClim 1.4 interpolation model with grid cell resolution $2.5 \mathrm{~min}$ for the period 1950-2000 (Hijmans et al. 2005) at (i) the species records as well as (ii) at 1,000 random points within both the MCP of the western and eastern Atelopus presence. For comparison, we computed boxplots with XLSTAT 2009 (Addinsoft). Subsequently, climate envelope models were generated and mapped with MaxEnt 3.2.19 (Phillips et al. 2006) based on the principle of maximum entropy (Jaynes 1957). This approach yields more reliable results than comparable methods (e.g. Elith et al. 2006; Heikkinen et al. 2006; Wisz et al. 2008), especially when data points for species number relatively few (e.g. Hernandez et al. 2006). Using default settings, $25 \%$ of the data points were randomly reserved for model testing (duplicate presence records in one grid cell were automatically removed). Prediction accuracy was evaluated through threshold-independent receiver operating characteristic (ROC) curves and the calculation of the area under the curve (AUC) method (e.g. Hanley and McNeil 1982). We acknowledge that there is currently some discussion about the suitability of AUC (Lobo et al. 2008). However, for our application AUC is the best possible choice. Elith and Graham (2009) pointed out that none of the frequently applied statistics in AUC are misleading and that appropriate statistics relevant to the application of the model need to be selected. The logistic MaxEnt output was chosen which is continuous and linear scaled ( $0-1$, with 0.1 being the minimum Maxent value at the training records already suggesting suitability to the species under study; Phillips et al. 2006).

We quantitatively compared climate envelopes of western and eastern Amazonian Atelopus with Schoener's index $(D)$ and Hellinger distance $(I)$ as modified by Warren et al. (2008). Both indices allow for testing climate envelope similarity between two probability distributions of (e.g. climate envelope) distributions over geographic space, whereby $D$ and $I$ values range from 0 to 1 (i.e. models have no to entire overlap). We evaluated the significance of $D$ and $I$ values with null models regarding climate envelope similarity and equivalency representing two extremes within the spectrum of niche conservatism (Warren et al. 2008). Tests were performed separately for each bioclimatic parameter in the manner of Rödder and Lötters (2009). Moreover, for climate envelope equivalency, we applied a 


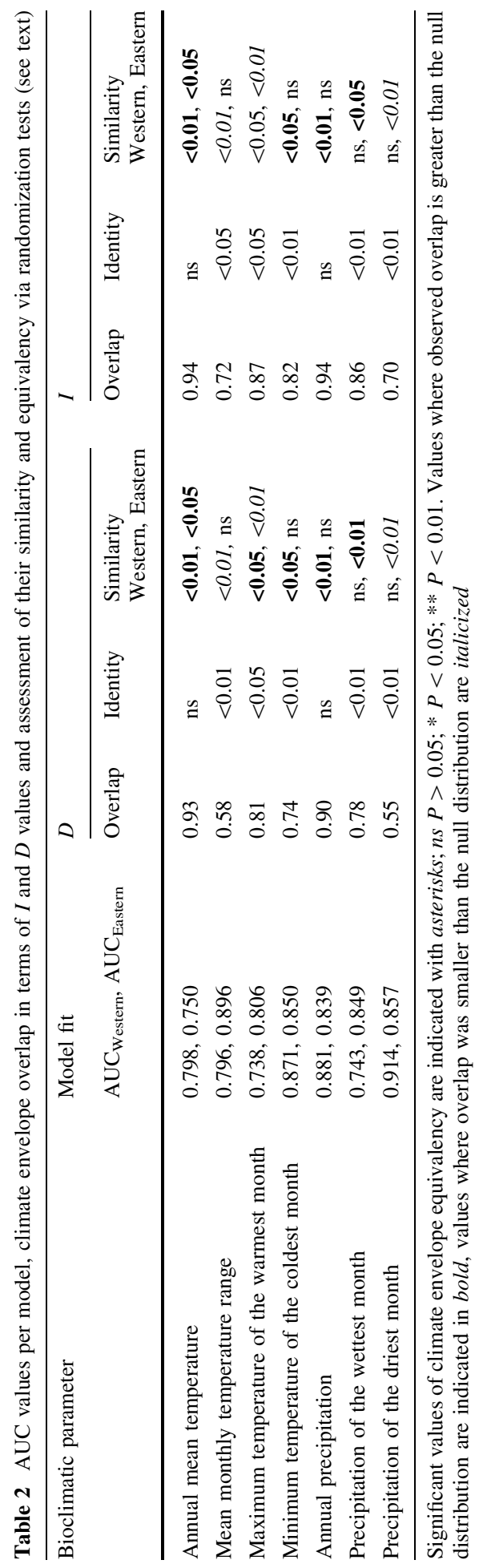


randomization test as proposed by Warren et al. (2008) which relies on the metrics $D$ and $I$. For western and eastern Amazonian harlequin frog occurrences 100 pseudoreplicate datasets were created by randomly partitioning the combined number of western and eastern occurrences into sets of the same size of the original of western and eastern datasets. Climate envelope models were built from each pseudoreplicate in order to generate null distributions. The overlap between models computed with the original data sets were compared to the percentiles of these null distributions in a one-tailed test to evaluate the hypothesis that climate envelope models for western and eastern records were not significantly different. This test allows for an assessment of climate envelope maintenance (i.e. niche conservancy) in a strict sense, i.e. the effective equivalency of the climate envelope in the western and eastern geographic ranges. It is expected to be only met if western and eastern harlequin frogs tolerate exactly the same set of climatic conditions and have the same set of environmental conditions available to them.

In order to assess climate envelope similarity, we again used a randomization test of Warren et al. (2008). It compares the actual similarity of climate envelopes in terms of $D$ and $I$ values to the distribution of similarities obtained by comparing them to a climate envelope model created through randomly choosing cells from among the cells in the study area. The same procedure was performed in both directions (western to eastern records vice versa) 100 times to construct an expected distribution of $D$ and $I$ values between a climate envelope model generated using actual occurrences and another one generated from random background data points extracted within a MCP enclosing one set of records. These null distributions served as a two-tailed test to assess the null hypothesis that measured climate envelope overlap between western and eastern Amazonian Atelopus is explained by regional similarities or differences in available habitat ('background effects'). This hypothesis is rejected if the actual similarity falls outside the $95 \%$ confidence limits of the null distribution suggesting active habitat choice. Significantly higher values suggest that climate envelopes are more similar than expected by chance and lower values indicate greater differences. Computations of $D, I$, climate envelope similarity and equivalency were performed with a Perl script developed by Warren et al. (2008).

\section{Results and discussion}

\section{A central Amazonian distribution gap}

Figure 2 suggests that indeed Amazonian harlequin frogs display a distribution gap in central Amazonia. Ripley's K function for presence data points revealed that they are above the function for randomly distributed points (Fig. 3), i.e. that the presence data are significantly clustered. Clustered presence data points endorse that a distribution gap exists, excluding the possibility that this pattern is caused by different sampling efforts in different areas, however. With respect to data of apparent absence, we acknowledge that it has to be regarded with care. Interpreting them under Ripley's K function, they fall within the confidence intervals of a random distribution (Fig. 3). This lets us tentatively conclude that it is unlikely that limited sampling efforts can be made responsible for the distribution gap identifiable in Fig. 2.

The existence of a natural distribution gap is expectable under DV (Fig. 1c) and therefore reinforces our hypothesis of Amazonian harlequin frog historical biogeography. However, it needs to be noted that this explanation for the observed geographic pattern is a single possibility out of many possible causes. A gap alone leaves also space for other explanations than DV. 

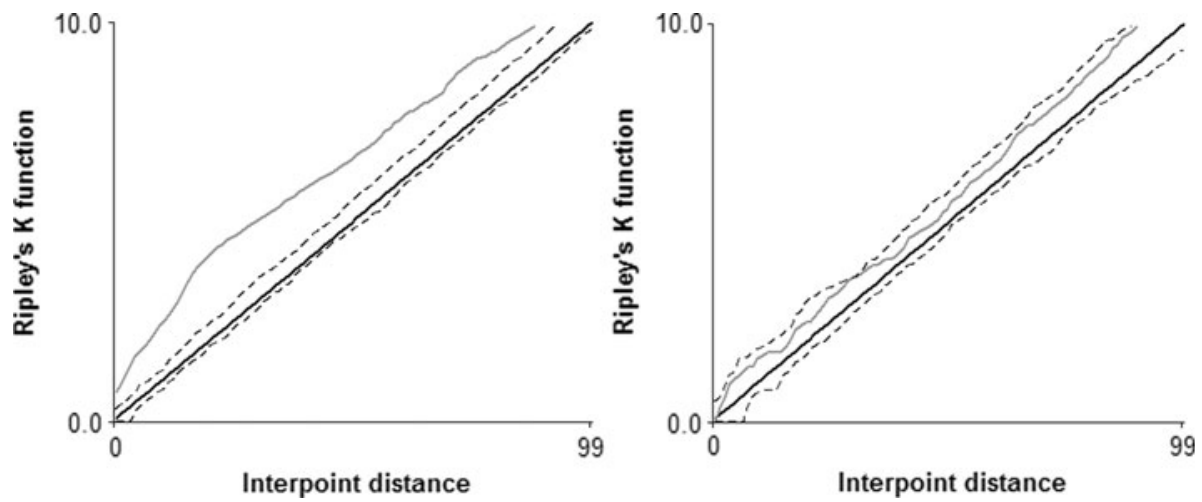

Fig. 3 Ripley's K functions showing that presence data points (left) are significantly inhomogeneous (i.e. clustered) while apparent absence data points are homogeneously distributed (compare Fig. 2). Bold black line: expected $\mathrm{K}$ function with lower and upper confidence envelopes (dashed), bold grey line: observed $\mathrm{K}$ function

\section{Nested monophyly of eastern Amazonian Atelopus}

Figure 4 illustrates a ML phylogram for 20 harlequin frogs and outgroups. All Amazonian Atelopus comprise a well supported monophyletic lineage, which is sister to all other members in the genus (i.e. a combination of Andean and trans-Andean species; Table 1). The species included in this group are the only Atelopus showing bright pink, violet or red coloured hand and foot soles, perhaps representing a synapomorphy (e.g. Lötters 1996; Lötters et al. 2002). Moreover, the only harlequin frogs known to possess a middle ear are included in this group (absent in most members of the genus; Lötters 1996). However, not all species used in our phylogeny have been studied for ear ossicle conditions, so that phylogenetic information can only be expected here (Fig. 4). Within this Amazonian clade, two sub-clades are evident, supported by high bootstrap and Bayesian posterior probability values. One includes the species from central to southern Peru and Bolivia, i.e. an A. tricolor-clade (see Fig. 4). The other is comprised of all studied species from the upper portion of the Amazon River plus the eastern Guiana Shield and the portion of the Amazon basin adjacent to it. Our data strongly support the eastern Guiana Shield Atelopus forming a monophyletic subset of this clade. Similar to the results of Noonan and Gaucher (2005), Guianan Atelopus are little differentiated, as reflected by the weak support of groupings among them. Our findings fully support Noonan and Gaucher (2005) who suggested that DV predictions are well applicable to harlequin frogs.

Atelopus species from the Venezuelan Andes and the Caribbean coastal range, i.e. proximate to the Guiana Shield, show osteological and external morphological characters suggesting a closer relationship to Colombian Andean taxa (McDiarmid 1971). However, we lack other characters, such as those from molecular phylogenetics studies, to validate or dispose this view.

Divergence in climate envelopes and allopatry

Prediction accuracy of MaxEnt climate envelope models was high as suggested by 'excellent' AUC values (western Amazonian Atelopus: test 0.955, training 0.980; eastern Amazonian Atelopus: test 0.979, training 0.985) following the AUC classification accuracy of Swets (1988). 
Fig. 4 ML phylogram of different Atelopus species from all over the genus' range (Table 1) based on the mitochondrial 16S rRNA gene showing that Amazonian Atelopus constitute a monophyletic unit with those from the eastern Guiana Shield nested within them. Numbers above branches indicate Maximum Likelihood bootstrap support/Bayesian posterior probabilities values. Species names are accompanied by GenBank accession numbers. This tree was rooted with Eleutherodactylus cf. johnstonei (not shown). It is also indicated in the Atelopus species if presence $(*)$ or absence $(* *)$ of a middle ear is known

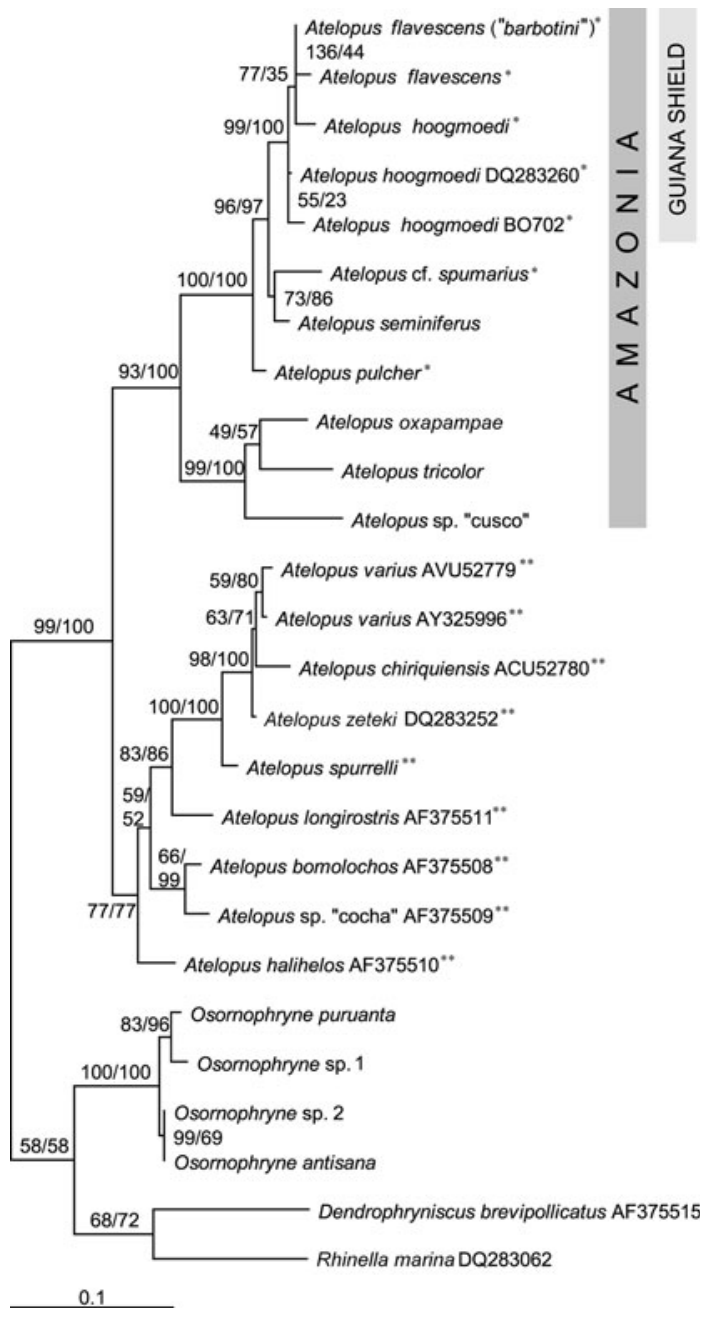

Comparing box plots (Fig. 5), the available climate space as well as climate envelopes of western and eastern Amazonian Atelopus are similar as ranges of all bioclimatic parameters in our modelling approach largely overlap. Two of the temperature parameters, 'annual mean temperature' and 'maximum temperature of the warmest month', are rather alike (i.e. not significantly different; Table 2), while one temperature and two of the precipitation parameters, 'mean monthly temperature range', 'precipitation of the wettest month' and 'precipitation of the driest month', show significant divergence (Table 2). These observations are highly coincident with the $D$ and $I$ values, which characterize the climate envelope overlap (Table 2). The niche identity tests revealed that the climate envelopes of eastern and western harlequin frogs were identical in terms of annual means of temperature and precipitation. The null hypothesis that climate envelopes are equivalent in the western and eastern ranges was rejected for all other parameters. The climate envelope similarity test revealed that overlap in the 'annual mean temperature' and the 'maximum temperature of the warmest month' can be most likely traced back to active habitat choice. These findings corroborate our expectation that climate envelopes of western and eastern Amazonian harlequin frogs show some 

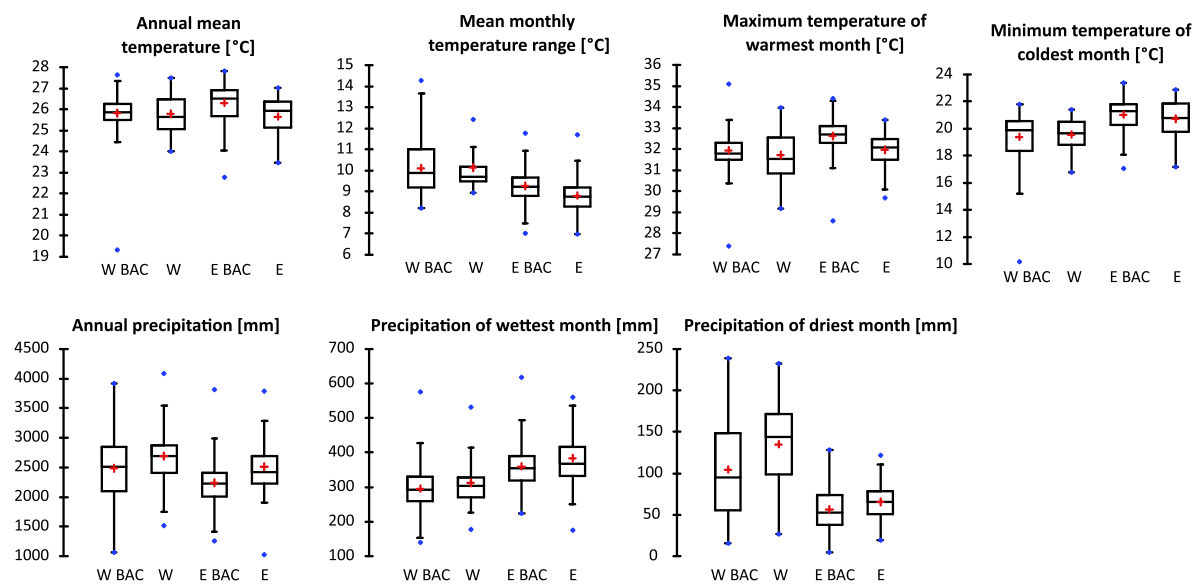

Fig. 5 Box plots of seven bioclimatic parameters in climate envelope models of western (W) and eastern Amazonian Atelopus (E) and available climate space within MCPs (W BAC; E BAC). Values given in the upper row refer to temperature in ${ }^{\circ} \mathrm{C}$ and those in the lower row refer to precipitation in $\mathrm{mm}$. Broad horizontal bars indicate the first and third quartiles as well as the median. Short horizontal bars indicate minimum/maximum values while dots do represent extremes outside $95 \%$ confidence intervals. Mean values are indicated by crosses

divergence. However, background effects (i.e. wide availability of suitable climate conditions) may at least partly explain the overlap observed for the other parameters. Whereas eastern Amazonian Atelopus actively chose their habitats according to some climate components which are only limitedly available to them, these same climate components may be widely available within the range of western Atelopus, where other components may be actually limiting. Such patterns are reasonable since different parameters may be widely available or limiting in eastern or western ranges influencing habitat choice. Hence, our findings suggest once cool-adapted Atelopus ancestors, under warm conditions, were forced to change climate envelopes.

Because 'excellent' AUC values suggest a high prediction accuracy (see above), we mapped climate envelope of western and eastern Amazonian Atelopus into geographic space on the full presence data point sets (i.e. this time no data points were set aside for testing). Doing so, it is possible to take advantage of all available information and to provide best estimated prediction maps (see Phillips et al. 2006). Results are shown in Fig. 6. Fitting well with the comparison of the climate envelops of the two units studied (Fig. 5; Table 2), their geographic distributions are largely allopatric with overlap corresponding to lower suitability (i.e. lower MaxEnt values). Areas of higher suitability of climate envelopes (i.e. warmer colours in Fig. 6) of western and eastern Amazonian Atelopus show little overlap.

\section{Conclusion}

We provide molecular phylogenetic evidence that all Amazonian Atelopus constitute a monophyletic group and find support that a natural distribution gap in central Amazonia for these amphibians exists. Harlequin frogs from east of this gap are a monophyletic subset, suggesting that they have derived from a single ancestral stock which subsequently has started vicariant speciation. Our findings corroborate the results of Noonan and Gaucher (2005). 
A

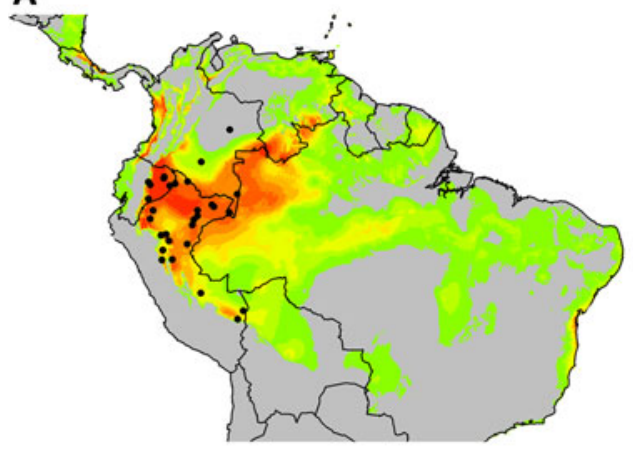

B

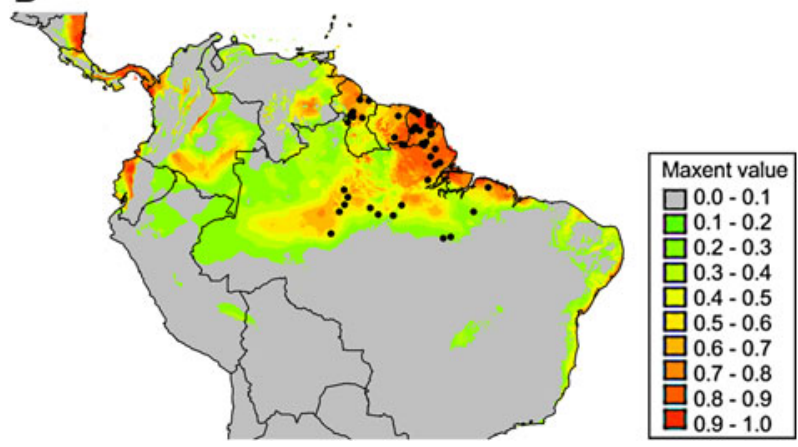

Fig. 6 Potential distributions of western (a) and eastern (b) Amazonian Atelopus. Colours from green via yellow to red refer to MaxEnt values of probability with warmer colours standing for areas with better predicted conditions (range 0-1, logistic MaxEnt output). Illustrations were performed with DIVA-GIS 5.4. (Color figure online)

These authors advocated that DV predictions are met in Amazonian and in particular eastern Guiana Shield Atelopus. We here demonstrate that DV predictions are also met when genetic sampling is expanded by inclusion of more species from the entire genus' distribution.

The justified spatial breakup into western and eastern Amazonian groups afforded us for the first time to derive DV predictions regarding climate envelope change in taxa of Andean origin. These predictions were met, as we were able to show that climate envelopes of both groups were similar regarding some parameters but that other parameters significantly differed. These different parameters result in allopatric potential distributions of western and eastern Amazonian Atelopus. Geographic range shift does not strictly result in climate envelope change, as commonly species tend to change their distributions with changing climate being bound to physiological constrains hampering climate envelope shifts regarding some parameters (e.g. Parmesan 2006). Because of the limited elevational range in the eastern Guiana Shield, cool-adapted taxa facing extinction risk were forced with a strong selective pressure to change their climate envelopes. We suggest that this is a prediction which is generally applicable to Andean species under DV.

Acknowledgments We are grateful to all collaborators who supported us with their knowledge on amphibian communities in Amazonia and the Guiana region (see Appendix), as well as to curators of scientific collections reviewed (E. Ahlander, W. Böhme, B.T. Clarke, J.H. Córdova, W.E. Duellman, L. Ford, J.D. Lynch, I. Sazima, H. Zaher). This project benefited from grants by the Wilhelm-Peters-Fonds 
of the Deutsche Gesellschaft für Herpetologie und Terrarienkunde (DGHT) to S. Lötters and M. Veith and by the Graduiertenförderung des Landes Nordrhein-Westfalen to D. Rödder. C.F.B. Haddad thanks FAPESP and $\mathrm{CNPq}$ for financial supports. For tissue samples processed in this paper, we thank D. Bernauer, M. Blanc, R. Boistel, L.A. Coloma, I. De la Riva, R. Ernst and E. Lehr. A. van der Meijden was supported by FCT postdoctoral grant SFRH/BPD/48042/2008. Special thanks to B.P. Noonan for helpful comments on a previous version of this paper.

Open Access This article is distributed under the terms of the Creative Commons Attribution Noncommercial License which permits any noncommercial use, distribution, and reproduction in any medium, provided the original author(s) and source are credited.

\section{Appendix}

\section{See Table 3.}

Table 3 List of localities in Amazonia and on the eastern Guiana Shield of presence and apparent absence of harlequin frogs (Atelopus)

\begin{tabular}{llll}
\hline Locality & $\begin{array}{l}\text { Approximate } \\
\text { location }\end{array}$ & $\begin{array}{l}\text { Presence } \\
\text { or apparent } \\
\text { absence }\end{array}$ & Source(s) \\
\hline
\end{tabular}

Bolivia (3 localities, 0 presence)

Cobija, Depto. Pando

Río Ortón, Depto. Pando

Tahuamanu, Depto. Pando

Brazil (39 localities, 21 presences)

Ajarani region, Edo. Roraima

Alto Rio Juruá region,

Edo. Amazonas

Baixo Rio Juruá region,

Edo. Amazonas

Belém region, Edo. Pará

Boa Vista region,

Edo. Roraima

Caiman region, Edo. Amapá

Chanpiom region, Edo. Pará

Carajás region, Edo. Pará

CEMEX, SE of Santarém, Edo. Pará

Cruzeiro do Sul, Edo. Acre

Igarapé de Piranha, Edo.

Amazonas

Ituxi region, Edo. Amazonas

Jacareacanga, Edo. Pará

Lago do Castanho,

Edo. Amazonas

Mamirauá region,

Edo. Amazonas

$\begin{array}{ll}11.01 \mathrm{~S}, 68.45 \mathrm{~W} & - \\ 10.58 \mathrm{~S}, 69.40 \mathrm{~W} & - \\ 11.24 \mathrm{~S}, 69.10 \mathrm{~W} & -\end{array}$

$02.0 \mathrm{~N}, 62.45 \mathrm{~W}$

$08.0 \mathrm{~S}, 72.50 \mathrm{~W}$

$03.15 \mathrm{~S}, 66.15 \mathrm{~W}$

$01.29 \mathrm{~S}, 48.24 \mathrm{~W}$

$02.49 \mathrm{~N}, 60.40 \mathrm{~W}$

$03.18 \mathrm{~N}, 52.15 \mathrm{~W}$

$01.20 \mathrm{~N}, 51.16 \mathrm{~W}$

$06.02 \mathrm{~S}, 50.25 \mathrm{~W}$

$03.09 \mathrm{~S}, 54.51 \mathrm{~W}$

07.37 S, 72.35 W

$05.43 \mathrm{~S}, 61.16 \mathrm{~W}$

$08.17 \mathrm{~S}, 65.30 \mathrm{~W}$

$01.32 \mathrm{~S}, 47.03 \mathrm{~W}$

$03.45 \mathrm{~S}, 60.30 \mathrm{~W}$

$03.30 \mathrm{~S}, 64.35 \mathrm{~W}$
Köhler and Lötters (1999)

I. De la Riva, pc;

S. Reichle, pc

I. De la Riva, pc;

S. Reichle, pc

C. Azevedo-Ramos, pc

C. Azevedo-Ramos, pc

C. Azevedo-Ramos, pc

C. Azevedo-Ramos, pc

J.P. Caldwell, pc

Lescure, (1981a)

C. Azevedo-Ramos, pc

C. Azevedo-Ramos, pc

J.P. Caldwell, pc

Authors' pers. observ.

MZUSP

C. Azevedo-Ramos, pc

ZUEC

ZUEC

C. Azevedo-Ramos, pc 
Table 3 continued

\begin{tabular}{|c|c|c|c|}
\hline Locality & $\begin{array}{l}\text { Approximate } \\
\text { location }\end{array}$ & $\begin{array}{l}\text { Presence } \\
\text { or apparent } \\
\text { absence }\end{array}$ & Source(s) \\
\hline Maués, Edo. Amazonas & $03.24 \mathrm{~S}, 57.42 \mathrm{~W}$ & + & $\mathrm{AMNH}$ \\
\hline Monte Cristo, Edo. Pará & $04.40 \mathrm{~S}, 55.38 \mathrm{~W}$ & + & MZUSP \\
\hline $\begin{array}{l}\text { Município de Castanho, } \\
\text { Edo. Amazonas }\end{array}$ & $03.30 \mathrm{~S}, 59.54 \mathrm{~W}$ & - & J.P. Caldwell, pc \\
\hline Paragominas region, Edo. Pará & $03.45 \mathrm{~S}, 48.20 \mathrm{~W}$ & + & C. Azevedo-Ramos, pc \\
\hline $\begin{array}{l}\text { PN da Serra do Divisor, } \\
\text { Edo. Acre }\end{array}$ & $08.20 \mathrm{~S}, 73.32 \mathrm{~W}$ & - & Authors' pers. observ. \\
\hline $\begin{array}{l}\text { Pojuca, Serra do Carajás, } \\
\text { Edo. Pará }\end{array}$ & $06.10 \mathrm{~S}, 51.05 \mathrm{~W}$ & + & ZUEC \\
\hline Porto Platon, Edo. Amapá & $00.42 \mathrm{~N}, 51.27 \mathrm{~W}$ & + & MZUSP \\
\hline Porto Grande, Edo. Amapá & $00.42 \mathrm{~N}, 51.24 \mathrm{~W}$ & + & ZUEC \\
\hline Porto Walter, Edo. Acre & $08.15 \mathrm{~S}, 72.47 \mathrm{~W}$ & - & J.P. Caldwell, pc \\
\hline $\begin{array}{l}\text { Presidente Figuereido, Edo. } \\
\text { Amazonas }\end{array}$ & $02.00 \mathrm{~S}, 60.00 \mathrm{~W}$ & - & Authors' pers. observ. \\
\hline $\begin{array}{l}\text { Reserva Campina, Edo. } \\
\text { Amazonas }\end{array}$ & $03.07 \mathrm{~S}, 60.03 \mathrm{~W}$ & + & ZUEC \\
\hline $\begin{array}{l}\text { Reserva INPA-WWF, Edo. } \\
\text { Amazonas }\end{array}$ & $02.25 \mathrm{~S}, 59.43 \mathrm{~W}$ & + & MZUSP \\
\hline Reserva Pacanari, Edo. Pará & $00.52 \mathrm{~S}, 52.31 \mathrm{~W}$ & + & ZUEC \\
\hline Rio Amaparí, Edo. Amapá & $01.15 \mathrm{~N}, 52.15 \mathrm{~W}$ & + & MZUSP \\
\hline Rio Formoso, Edo. Rondônia & $10.19 \mathrm{~S}, 64.34 \mathrm{~W}$ & - & J.P. Caldwell, pc \\
\hline Rio Ituxi, Edo. Amazonas & $08.29 \mathrm{~S}, 65.43 \mathrm{~W}$ & - & J.P. Caldwell, pc \\
\hline Rio Manjuru, Edo. Amazonas & $04.00 \mathrm{~S}, 57.00 \mathrm{~W}$ & + & AMNH \\
\hline Rio Maú, Edo. Roraima & $04.20 \mathrm{~N}, 59.45 \mathrm{~W}$ & + & MZUSP \\
\hline Serra do Navio, Edo. Amapá & $01.55 \mathrm{~N}, 51.50 \mathrm{~W}$ & + & $\begin{array}{l}\text { MZUSP; McDiarmid } \\
\quad \text { (1973) }\end{array}$ \\
\hline $\begin{array}{l}\text { Terra Verde Lodge, Edo. } \\
\text { Amazonas }\end{array}$ & $03.37 \mathrm{~S}, 59.86 \mathrm{~W}$ & - & J.P. Caldwell, pc \\
\hline Urucú region, Edo. Amazonas & $05.00 \mathrm{~S}, 65.30 \mathrm{~W}$ & - & C. Azevedo-Ramos, pc \\
\hline $\begin{array}{l}\text { Circa } 90 \mathrm{~km} \mathrm{~N} \text { of Manaus, } \\
\text { Edo. Amazonas }\end{array}$ & $01.45 \mathrm{~S}, 60.05 \mathrm{~W}$ & + & Gascon (1989) \\
\hline $\begin{array}{l}1.0 \text { km NW of Caracaraí, Edo. } \\
\text { Roraima }\end{array}$ & $01.50 \mathrm{~N}, 61.08 \mathrm{~W}$ & - & J.P. Caldwell, pc \\
\hline \multicolumn{4}{|c|}{ Colombia (11 localities, 3 presences) } \\
\hline Calderón, Depto. Amazonas & $03.46 \mathrm{~S}, 69.53 \mathrm{~W}$ & - & $\begin{array}{l}\text { Ardila-R. and Ruiz-C } \\
\text { (1997) }\end{array}$ \\
\hline $\begin{array}{l}\text { Caño Cabina, Léticia, Depto. } \\
\text { Amazonas }\end{array}$ & $03.40 \mathrm{~N}, 70.25 \mathrm{~W}$ & + & J.M. Renjifo, pc \\
\hline Igara Parana, Depto. Amazonas & $00.44 \mathrm{~N}, 72.58 \mathrm{~W}$ & + & BM; Lescure, (1981a) \\
\hline La Pedrera, Depto. Amazonas & $01.18 \mathrm{~S}, 69.22 \mathrm{~W}$ & - & $\begin{array}{l}\text { Ardila-R. and Ruiz-C } \\
\text { (1997) }\end{array}$ \\
\hline Río Apaporis, Depto. Vaupes & $00.45 \mathrm{~N}, 72.00 \mathrm{~W}$ & - & J.M. Renjifo, pc \\
\hline Río Mirití, Depto. Amazonas & $01.12 \mathrm{~S}, 69.53 \mathrm{~W}$ & - & $\begin{array}{l}\text { Ardila-R. and Ruiz-C, } \\
\text { (1997) }\end{array}$ \\
\hline Río Puré, Depto. Putumayo & $02.10 \mathrm{~S}, 69.42 \mathrm{~W}$ & + & $\mathrm{ICN}$ \\
\hline
\end{tabular}


Table 3 continued

\begin{tabular}{|c|c|c|c|}
\hline Locality & $\begin{array}{l}\text { Approximate } \\
\text { location }\end{array}$ & $\begin{array}{l}\text { Presence } \\
\text { or apparent } \\
\text { absence }\end{array}$ & Source(s) \\
\hline Río Tiquie, Depto. Vaupes & $00.20 \mathrm{~N}, 70.20 \mathrm{~W}$ & - & J.M. Renjifo, pc \\
\hline Tarapacá, Depto. Amazonas & $02.52 \mathrm{~S}, 69.44 \mathrm{~W}$ & - & $\begin{array}{l}\text { Ardila-R. and Ruiz-C, } \\
\text { (1997) }\end{array}$ \\
\hline Tomachipan, Depto. Guaviare & $02.18 \mathrm{~S}, 71.46 \mathrm{~W}$ & - & J.M. Renjifo, pc \\
\hline $\begin{array}{l}\text { Serrania de Taraira, Depto. } \\
\text { Vaupes }\end{array}$ & $00.55 \mathrm{~S}, 69.40 \mathrm{~W}$ & - & J.M. Renjifo, pc \\
\hline \multicolumn{4}{|l|}{ Ecuador (8 localities, 7 presences) } \\
\hline $\begin{array}{l}\text { Cuyabeno Reserve, Prov. } \\
\text { Sucumbíos }\end{array}$ & $00.00,76.00 \mathrm{~W}$ & - & $\begin{array}{l}\text { L.A. Coloma, pc; J.P. } \\
\text { Caldwell, pc }\end{array}$ \\
\hline $\begin{array}{l}\text { Jatun Sacha Reserve, Prov. } \\
\text { Napo }\end{array}$ & $01.05 \mathrm{~S}, 77.45 \mathrm{~W}$ & + & L.A. Coloma, pc \\
\hline Miazal, Prov. Morona-Santiago & $02.37 \mathrm{~S}, 77.47 \mathrm{~W}$ & + & Rivero (1968) \\
\hline PN Yasuní, Prov. Orellana & $00.36 \mathrm{~S}, 76.20 \mathrm{~W}$ & + & QCAZ \\
\hline Río Cononaco, Prov. Orellana & $01.25 \mathrm{~S}, 75.50 \mathrm{~W}$ & + & Patzelt (1989) \\
\hline Río Oglán, Prov. Pastaza & $01.19 \mathrm{~S}, 77.35 \mathrm{~W}$ & + & Rivero (1968) \\
\hline Río Villano, Prov. Pastaza & $01.29 \mathrm{~S}, 77.38 \mathrm{~W}$ & + & $\mathrm{BM}$ \\
\hline $\begin{array}{l}\text { Circa } 66 \text { km E of Pompeya, PN } \\
\text { Yasuní, Prov. Orellana }\end{array}$ & $00.45 \mathrm{~S}, 76.21 \mathrm{~W}$ & + & QCAZ \\
\hline \multicolumn{4}{|c|}{ French Guiana (24 localities, 24 presences) } \\
\hline Between Dorlin and Sophie & $03.51 \mathrm{~N}, 53.34 \mathrm{~W}$ & + & McDiarmid (1973) \\
\hline Between La Greve and Sophie & $03.57 \mathrm{~N}, 53.35 \mathrm{~W}$ & + & McDiarmid (1973) \\
\hline Boulanger & $04.32 \mathrm{~N}, 52.25 \mathrm{~W}$ & + & ZFMK \\
\hline Cayenne region* & $04.50 \mathrm{~N}, 52.22 \mathrm{~W}$ & + & Lescure (1976) \\
\hline Chaumière & $04.53 \mathrm{~N}, 52.22 \mathrm{~W}$ & + & Lescure (1973) \\
\hline Crique Grégoire (Kerenroch) & $05.05 \mathrm{~N}, 53.20 \mathrm{~W}$ & + & Lescure (1973) \\
\hline Crique Ipoucin & $04.09 \mathrm{~N}, 52.25 \mathrm{~W}$ & + & Lescure (1976) \\
\hline Kaw region & $04.29 \mathrm{~N}, 52.20 \mathrm{~W}$ & + & Lescure $(1976,1981 b)$ \\
\hline Koulimapopane & $02.19 \mathrm{~N}, 54.36 \mathrm{~W}$ & + & Lescure (1976) \\
\hline Maripasoula & $03.36 \mathrm{~N}, 53.12 \mathrm{~W}$ & + & NRM \\
\hline Matoury & $04.50 \mathrm{~N}, 52.25 \mathrm{~W}$ & + & Lescure (1976) \\
\hline Montagne Belvédère* & $03.37 \mathrm{~N}, 53.14 \mathrm{~W}$ & + & Kok (2000) \\
\hline Montagne Saint-Marcel & $02.25 \mathrm{~N}, 53.00 \mathrm{~W}$ & + & Lescure (1981a) \\
\hline Monts Atachi-Bacca & $03.35 \mathrm{~N}, 54.00 \mathrm{~W}$ & + & Lescure (1976) \\
\hline Petit Saut & $05.21 \mathrm{~N}, 53.41 \mathrm{~W}$ & + & $\begin{array}{l}\text { Hoogmoed and Avila- } \\
\text { Pires (1991) }\end{array}$ \\
\hline Rivière Matarony & $04.02 \mathrm{~N}, 52.15 \mathrm{~W}$ & + & McDiarmid (1973) \\
\hline Rivière Yaroupi & $02.35 \mathrm{~N}, 52.40 \mathrm{~W}$ & + & Lescure (1976) \\
\hline Roura region & $04.45 \mathrm{~N}, 52.20 \mathrm{~W}$ & + & Lescure (1976) \\
\hline Saint Laurent region & $05.30 \mathrm{~N}, 53.55 \mathrm{~W}$ & + & Lescure (1981a) \\
\hline Saül region* & $03.35 \mathrm{~N}, 53.56 \mathrm{~W}$ & + & Lescure (1981a) \\
\hline Sophie region & $03.55 \mathrm{~N}, 53.40 \mathrm{~W}$ & + & Lescure (1981a) \\
\hline Tortue region & $04.11 \mathrm{~N}, 52.23 \mathrm{~W}$ & + & Lescure (1976) \\
\hline
\end{tabular}


Table 3 continued

\begin{tabular}{|c|c|c|c|}
\hline Locality & $\begin{array}{l}\text { Approximate } \\
\text { location }\end{array}$ & $\begin{array}{l}\text { Presence } \\
\text { or apparent } \\
\text { absence }\end{array}$ & Source(s) \\
\hline Trois-Sauts & $02.15 \mathrm{~N}, 52.50 \mathrm{~W}$ & + & $\begin{array}{l}\text { Lescure (1981a); Lescure } \\
\text { and Gasc (1986) }\end{array}$ \\
\hline Circa $30 \mathrm{~km} \mathrm{~S}$ of Saül & $03.20 \mathrm{~N}, 52.10 \mathrm{~W}$ & + & Lescure (1981a) \\
\hline \multicolumn{4}{|l|}{ Guiana (9 localities, 9 presences) } \\
\hline $\begin{array}{l}\text { Between Chenapowu and } \\
\text { Saveritih }\end{array}$ & $04.55 \mathrm{~N}, 59.34 \mathrm{~W}$ & + & AMNH \\
\hline Demerara River & $04.47 \mathrm{~N}, 58.26 \mathrm{~W}$ & + & AMNH \\
\hline Iwokrama & $04.50 \mathrm{~N}, 59.15 \mathrm{~W}$ & + & M.L. Donnelly, pc \\
\hline Kalacoon & $06.24 \mathrm{~N}, 58.39 \mathrm{~W}$ & + & $\begin{array}{l}\text { AMNH; McDiarmid, } \\
\text { (1973) }\end{array}$ \\
\hline Kangaruma & $05.18 \mathrm{~N}, 59.17 \mathrm{~W}$ & + & $\begin{array}{l}\text { AMNH; McDiarmid } \\
\quad(1973)\end{array}$ \\
\hline Karisparu & $04.58 \mathrm{~N}, 59.30 \mathrm{~W}$ & + & $\mathrm{BM}$ \\
\hline Kartabo & $06.21 \mathrm{~N}, 57.50 \mathrm{~W}$ & + & $\begin{array}{l}\text { AMNH; McDiarmid } \\
\text { (1973) }\end{array}$ \\
\hline Potaro River & $05.20 \mathrm{~N}, 59.17 \mathrm{~W}$ & + & $\mathrm{BM}$ \\
\hline 25 mi WSW of Mabura Hill** & $05.13 \mathrm{~N}, 59.21 \mathrm{~W}$ & + & AMNH \\
\hline \multicolumn{4}{|l|}{ Peru (31 localities, 21 presences) } \\
\hline Achinamisa, Depto. San Martín & $06.25 \mathrm{~S}, 75.54 \mathrm{~W}$ & + & AMNH \\
\hline Balta, Depto. Ucayali & $10.08 \mathrm{~S}, 71.13 \mathrm{~W}$ & - & $\begin{array}{l}\text { Duellman and Thomas } \\
\text { (1996) }\end{array}$ \\
\hline Barranca, Depto. San Martín & $07.16 \mathrm{~S}, 76.28 \mathrm{~W}$ & + & AMNH \\
\hline $\begin{array}{l}\text { Bolognesi region, Depto. } \\
\text { Ucayali }\end{array}$ & $10.02 \mathrm{~S}, 73.57 \mathrm{~W}$ & - & Lehr (2002) \\
\hline Cachiyacu, Depto. San Martín & $05.44 \mathrm{~S}, 77.29 \mathrm{~W}$ & + & Rivero (1968) \\
\hline Chayahuitas, Depto. Loreto & $05.50 \mathrm{~S}, 76.10 \mathrm{~W}$ & + & $\begin{array}{l}\text { Rivero (1968); Lötters } \\
\text { et al. (2002) }\end{array}$ \\
\hline $\begin{array}{l}\text { Cocha Cashu/PN Manu, Depto. } \\
\text { Madre de Dios }\end{array}$ & $11.54 \mathrm{~S}, 71.22 \mathrm{~W}$ & - & Rodríguez (1992) \\
\hline $\begin{array}{l}\text { Cuzco Amazónico, Madre de } \\
\text { Dios }\end{array}$ & $12.35 \mathrm{~S}, 69.05 \mathrm{~W}$ & - & $\begin{array}{l}\text { Duellman and Salas } \\
\text { (1991) }\end{array}$ \\
\hline Explorama, Depto. Loreto & $02.35 \mathrm{~S}, 71.57 \mathrm{~W}$ & - & $\begin{array}{l}\text { Duellman and Thomas } \\
\text { (1996) }\end{array}$ \\
\hline Genaro Herrera, Depto. Loreto & $04.59 \mathrm{~S}, 73.46 \mathrm{~W}$ & + & MUSM \\
\hline Iquitos region, Depto. Loreto* & $03.40 \mathrm{~S}, 73.20 \mathrm{~W}$ & + & $\begin{array}{l}\text { AMNH; Rodríguez and } \\
\text { Duellman (1994) }\end{array}$ \\
\hline Manseriche, Depto. Loreto & $04.25 \mathrm{~S}, 77.35 \mathrm{~W}$ & + & Rivero (1968) \\
\hline Milagros, Depto. Ucayali & $10.08 \mathrm{~S}, 74.01 \mathrm{~W}$ & - & Lehr (2002) \\
\hline Monte Alegre, Depto. Loreto & $06.42 \mathrm{~S}, 74.15 \mathrm{~W}$ & + & AMNH \\
\hline Nauta region, Depto. Loreto & $04.30 \mathrm{~S}, 73.40 \mathrm{~W}$ & + & Asquith and Altig (1987) \\
\hline Panguana, Depto. Huánuco & $09.35 \mathrm{~S}, 74.48 \mathrm{~W}$ & - & Schlüter (2005) \\
\hline Pebas region, Depto. Loreto & $03.20 \mathrm{~S}, 71.50 \mathrm{~W}$ & + & AMNH; Lescure (1981a) \\
\hline Roabaya, Depto. Loreto & $04.10 \mathrm{~S}, 73.20 \mathrm{~W}$ & + & Rivero (1968) \\
\hline Río Ampiyacu, Depto. Loreto & $03.10 \mathrm{~S}, 72.00 \mathrm{~W}$ & + & Lötters et al. (2002) \\
\hline
\end{tabular}


Table 3 continued

\begin{tabular}{|c|c|c|c|}
\hline Locality & $\begin{array}{l}\text { Approximate } \\
\text { location }\end{array}$ & $\begin{array}{l}\text { Presence } \\
\text { or apparent } \\
\text { absence }\end{array}$ & Source(s) \\
\hline Río Cachiyacu, Depto. Loreto & $08.09 \mathrm{~S}, 76.32 \mathrm{~W}$ & + & Lötters et al. (2002) \\
\hline Río Loretoyacu, Depto. Loreto & $03.49 \mathrm{~S}, 70.26 \mathrm{~W}$ & + & AMNH \\
\hline Río Pisqui, Depto. Loreto & $08.05 \mathrm{~S}, 75.35 \mathrm{~W}$ & + & Lötters et al. (2002) \\
\hline Río Sepahua, Depto. Ucayali & $11.10 \mathrm{~S}, 73.01 \mathrm{~W}$ & + & Rivero (1968) \\
\hline Río Távara, Depto. Puno* & $13.31 \mathrm{~S}, 69.41 \mathrm{~W}$ & + & $\begin{array}{l}\text { Bärtschi and MacQuarrie } \\
\text { (2001) }\end{array}$ \\
\hline Río Tambo, Depto. Loreto & $01.15 \mathrm{~S}, 75.21 \mathrm{~W}$ & + & Rivero (1968) \\
\hline Río Yubineto, Depto. Loreto & $01.02 \mathrm{~S}, 74.13 \mathrm{~W}$ & + & $\begin{array}{l}\text { Lescure and Gasc (1986), } \\
\text { Lescure (1981a) }\end{array}$ \\
\hline San Jacinto, Depto. Loreto & $02.19 \mathrm{~S}, 75.52 \mathrm{~W}$ & - & $\begin{array}{l}\text { Duellman and Mendelson } \\
\text { (1995) }\end{array}$ \\
\hline Tacsha, Depto. Loreto & $03.40 \mathrm{~S}, 77.21 \mathrm{~W}$ & + & Rivero (1968) \\
\hline $\begin{array}{l}\text { Tambopata, Depto. Madre de } \\
\text { Dios }\end{array}$ & $12.44 \mathrm{~S}, 69.11 \mathrm{~W}$ & + & MUSN \\
\hline Teniente López, Depto. Loreto & $02.36 \mathrm{~S}, 76.07 \mathrm{~W}$ & - & $\begin{array}{l}\text { Duellman and Mendelson } \\
\text { (1995) }\end{array}$ \\
\hline Yurimaguas, Depto. Loreto & $05.54 \mathrm{~S}, 76.05 \mathrm{~W}$ & - & Authors' pers. observ \\
\hline \multicolumn{4}{|c|}{ Suriname (4 localities, 3 presences) } \\
\hline Brownsberg & $04.55 \mathrm{~N}, 55.10 \mathrm{~W}$ & + & AMNH, KU \\
\hline Corentijne River & $05.10 \mathrm{~N}, 57.20 \mathrm{~W}$ & - & S. Reichle, pc \\
\hline Monts Tumuc-Humac & $02.20 \mathrm{~N}, 54.40 \mathrm{~W}$ & + & Lescure $(1976,1981 a)$ \\
\hline Mt. Kasikasima & $03.00 \mathrm{~N}, 55.30 \mathrm{~W}$ & + & MZUSP \\
\hline \multicolumn{4}{|l|}{ Venezuela (1 locality, 0 presence) } \\
\hline Cerro Duida, Edo. Amazonas & $03.30 \mathrm{~N}, 65.40 \mathrm{~W}$ & & \\
\hline
\end{tabular}

As an altitudinal limit $800 \mathrm{~m}$ above sea level was chosen here (i.e. the approximate upper border of the tierra caliente lowlands). Localities in this list from where samples were used for molecular analyses are marked by an asterisk. Abbreviations: Depto. Departamento; Edo. Estado; Prov. Provincia; PN Parque Nacional; + present; - apparently absent; $p c$ personal communication; AMNH American Museum of Natural History, New York; BM British Museum (Natural History), London; ICN Instituto de Ciencias Naturales, Universidad Nacional de Colombia, Santafé de Bogotá; $K U$ Natural History Museum, The University of Kansas, Lawrence; MUSM Museo de Historia Natural de la Universidad Nacional Mayor de San Marcos, Lima; MZUSP Museu de Zoologia, Universidade de São Paulo; NRM Naturhistoriska Rijkmuseet, Stockholm; QCAZ Pontificia Universidad Católica del Ecuador, Quito; ZFMK Zoologisches Forschungsmuseum Alexander Koenig, Bonn; ZUEC Museu de História Natural, Universidade Estadual de Campinas, São Paulo

\section{References}

Antonelli A, Nylander JAA, Persson C, Sanmartín I (2009) Tracing the impact of the Andean uplift on Neotropical plant evolution. PNAS 106:9749-9754

Ardila-R MC, Ruiz-C PM (1997) Herpetología (anfibios/reptiles). In: Botero PJ (ed) Zonificación ambiental para el plan modelo Colombo-Brasilero (Eje Apaporis-Tabatinga: PAT). Editorial Linotipia Bolívar, Bogotá

Asquith A, Altig R (1987) Anura. Atelopus spumarius. Vocalization. Herp Rev 18:32-33

Atteslander P (2008) Methoden der empirischen Sozialforschung, 10th edn. W. de Gruyter, Berlin 
Bärtschi A, MacQuarrie K (2001) Where the Andes meet the Amazon. Peru and Bolivia's Bahuaja-Sonene and Madidi National Parks. Patthey and Sons, Barcelona

Benson DA, Karsch-Mitzrachi I, Lippman DJ et al (2004) GenBank: update. Nucl Acid Res 32:23-26

Broennimann O, Treier UA, Müller-Schärer H et al (2007) Evidence of climatic nich shift during biological invasion. Ecol Lett 10:701-709

Bruford MW, Hanotte O, Brookfield JFY, Burke T (1992) Single-locus and multilocus DNA fingerprinting. In: Hoezel AR (ed) Molecular genetic analysis in conservation. IRL Press, Oxford

Bush MB (1994) Amazonian speciation: a necessarily complex model. J Biogeogr 21:5-17

Carnaval AC, Moritz C (2008) Historical climate modelling predicts patterns of current biodiversity in the Brazilian Atlantic forest. J Biogeogr 35:1187-1201

Duellman WE, Mendelson JR III (1995) Amphibians and reptiles from northern Departamento Loreto, Peru: taxonomy and biogeography. Univ Kans Sci Bull 55:329-376

Duellman WE, Salas AW (1991) Annotated checklist of the amphibians and reptiles of Cuzco Amazonico, Peru. Occ Pap Mus Nat Hist Univ Kans 143:1-13

Duellman WE, Thomas R (1996) Anuran amphibians from a seasonally dry forest in southeastern Peru and comparisons among sites in the upper Amazon basin. Occ Pap Mus Nat Hist Univ Kans 180:1-34

Dutech C, Maggia L, Tardy C, Joly HI, Jarne P (2003) Tracking a genetic signal of extinction-recolonization events in a Neotropical tree species: Vоиасароиа americana Aublet in French Guiana. Evolution $57: 2753-2764$

Elith J, Graham CH (2009) Do they? How do they? Why do they differ? On finding reasons for differing performance of species distribution models. Ecography 32:66-77

Elith J, Graham CH, Anderson P et al (2006) Novel methods improve prediction of species' distributions from occurrence data. Ecography 29:129-151

Figueiredo J, Hoorn C, van der Ven P, Soares E (2009) Late Miocene onset of the Amazon River and the Amazon deep-sea fan: evidence from the Foz do Amazonas Basin. Geology 37:619-622

Gascon C (1989) The tadpole of Atelopus pulcher Boulenger (Annura [sic!], Bufonidae) from Manaus, Amazonas. Rev bras Zool 6:235-239

Guindon S, Gascuel O (2003) A simple, fast, and accurate algorithm to estimate large phylogenies by maximum likelihood. Syst Biol 52:696-704

Haase P (1995) Spatial pattern analysis in ecology based Ripley's K-functions: introduction and methods for edge correction. J Veg Sci 6:757-782

Haffer J (1997) Alternative models of vertebrate speciation in Amazonia: an overview. Biodivers Conserv 6:451-476

Haffer J (2008) Hypotheses to explain the origin of species in Amazonia. Braz J Biol 68:917-947

Hall JPW, Harvey DJ (2002) The phylogeography of Amazonia revisited: new evidence from riodinid butterflies. Evolution 56:1489-1497

Hanley J, McNeil B (1982) The meaning of the use of the area under a receiver operating characteristic (ROC) curve. Radiology 143:29-36

Heikkinen RK, Luoto M, Araùjo MB et al (2006) Methods and uncertainties in bioclimatic envelope modelling under climate change. Progr Phys Geogr 30:751-777

Hernandez PA, Graham CH, Master LL, Albert DL (2006) The effect of sample size and species characteristics on performance of different species distribution modeling methods. Ecography 29:773-785

Hijmans RJ, Guarino L, Cruz M, Rojas E (2001) Computer tools for spatial analysis of plant genetic resources data: 1. DIVA-GIS. Plant Gen Resour News1 127:15-19

Hijmans RJ, Cameron SE, Parra JL et al (2005) Very high resolution interpolated climatic surfaces for global land areas. Int J Climat 25:1965-1978

Hill LL, Zheng Q (1999) Indirect geospatial referencing through place names in the digital library: Alexandria Digital Library experience with developing and implementing gazetteers. Proc Amer Soc Inform Sci 1999:57-69

Holt RD, Gomulkiewicz R (2004) Conservation implication of niche conservatism and evolution in heterogeneous environments. In: Ferriere R, Dieckmann U, Couvet D (eds) Evolutionary conservation biology. Cambridge University Press, Cambridge

Holt RD, Barfield M, Gomulkiewicz R (2005) Theories of niche conservatism and evolution: could exotic species be potential tests? In: Sax D, Stachowicz J, Gaines SD (eds) Species invasions: insights into ecology, evolution, and biogeography. Sinauer Associates, Sunderland, MA

Hoogmoed MS, Avila-Pires TCS (1991) Annotated checklist of the herpetofauna of Petiti Saut, Sinnamary River, French Guiana. Zool Mededel 65:53-88

Hoorn C (2006) The birth of the mighty Amazon. Sci Amer 294:52-59

Huelsenbeck JP, Ronquist F (2001) MrBayes: Bayesian inference of phylogenetic trees. Bioinformatics 17:754-755 
Jakob SS, Heibl C, Rödder D, Blattner FR (2010) Population demography influences climatic niche evolution: evidence from diploid American Hordeum species (Poaceae). Mol Ecol 19:1423-1438

Jaynes ET (1957) Information theory and statistical mechanics. Phys Rev 106:620-630

Köhler J, Lötters S (1999) Annotated list of amphibian records from the Departamento Pando, Bolivia, with description of some advertisement calls. Bonn zool Beitr 48:259-273

Kok PJR (2000) A survey of the anuran fauna of Montagne Belvédère, county of Saül, French Guiana: field list with comments on taxonomy and ecology. Brit Herp Soc Bull 71:6-26

La Marca E, Lips KR, Lötters S, Puschendorf R, Ibáñez R, Rueda-Almonacid JV, Schulte R, Marty C, Castro F, Manzanilla-Puppo J, García-Pérez JE, Bolaños F, Chaves G, Pounds JA, Toral E, Young BE (2005) Catastrophic population declines and extinctions in Neotropical harlequin frogs (Bufonidae: Atelopus). Biotropica 37:190-201

Lehr E (2002) Amphibien und Reptilien in Peru. Natur- und Tier-Verlag, Münster

Lescure J (1973 “1972”) Contribution à l'étude des amphibiens de Guyane française. I. Notes sur Atelopus flavescens Duméril et Bibron et description d'une nouvelle espèce. Vie Milieu 23:125-141

Lescure J (1976) Contribution à l'étude des amphibiens de Guyane française. VI. Liste préliminaire des anoures. Bull Mus Nat Hist Nat Paris 265:475-525

Lescure J (1981a) Contribution à l'étude des amphibiens de Guyane française. VIII. Validation d'Atelopus spumarius Cope, 1871, et désignation d'un néotype. Description d'Atelopus spumarius barbotini nov. ssp. Donées étho-écologiques et biogéographiques sur les Atelopus du groupe flavescens (anoures, bufonidés). Bull Mus Nat Hist Nat Paris (sér. 4) 3:893-910

Lescure J (1981b) Reference à l'étude des amphibiens de Guyane française. IX. Le têtard gastromyzophore d'Atelopus flavescens Duméril et Bibron (Anura, Bufonidae). Amphib-Reptil 2:209-215

Lescure J, Gasc JP (1986) Partage de l'espace forestier par les amphibiens et les reptiles en Amazonie du nord-ouest. Caldasia 15:707-723

Lobo JM, Jiménez-Valverde A, Real R (2008) AUC: a misleading measure of the performance of predictive distribution models. Glob Ecol Biogeogr 17:145-151

Lötters S (1996) The neotropical toad genus Atelopus. Checklist-biology—distribution. Vences and Glaw, Cologne

Lötters S, Haas W, Schick S, Böhme W (2002) On the systematics of the harlequin frogs (Amphibia: Bufonidae: Atelopus) from Amazonia. II: redescription of Atelopus pulcher (Boulenger, 1882) from the eastern Andean versant in Peru. Salamandra 38:165-184

McDiarmid RW (1971) Comparative morphology and evolution of frogs of the Neotropical genera Atelopus, Dendrophryniscus, Melanophryniscus, and Oreophrynella. Sci Bull Los Angeles Co Mus Nat Hist 12:1-66

McDiarmid RW (1973) A new species of Atelopus (Anura, Bufonidae) from northeastern South America. Contrib Sci 240:1-12

Noonan BP, Gaucher P (2005) Phylogeography and demography of Guianan harlequin toads (Atelopus): diversification within a refuge. Mol Ecol 14:3017-3031

Noonan BP, Gaucher P (2006) Refugial isolation and secondary contact in the dyeing poison frog Dendrobates tinctorius. Mol Ecol 15:4425-4435

Noonan BP, Wray KP (2006) Neotropical diversification: the effects of a complex history on diversity within the poison frog genus Dendrobates. J Biogeogr 33:1007-1020

Palumbi S, Martin A, Romano S, McMillan WO, Stice L, Grabowski G (1991) The simple fool's guide to PCR. Version 2. Privately published document compiled by S. Palumbi. Department of Zoology, University Hawaii. Honolulu

Parmesan C (2006) Ecological and evolutionary responses to recent climate change. Annu Rev Ecol Evol Syst 37:637-669

Patzelt E (1989) Fauna del Ecuador. Banco Central del Ecuador, Quito

Pearman PB, Guisan A, Broennimann O, Randin CF (2007) Niche dynamics in space and time. Trends Ecol Evol 23:149-158

Peterson AT, Soberón J, Sánchez-Cordero V (1999) Conservation of ecological niches in evolutionary time. Science 285:1265-1267

Phillips SJ, Anderson RP, Shapire RE (2006) Maximum entropy modeling of species geographic distributions. Ecol Model 190:231-259

Posada D, Crandall KA (1998) Modeltest: testing the model of DNA substitution. Bioinform 14:817-818

Ripley BD (1977) Modelling spatial patterns (with discussion). J R Stat Soc Ser B 39:172-212

Rivero JA (1968) More on the Atelopus (Amphibia, Salientia) from western South America. Carib J Sci 8:19-29

Rödder D, Lötters S (2009) Niche shift or niche conservatism? Climatic properties of the native and invasive range of the Mediterranean Housegecko Hemidactylus turcicus. Glob Ecol Biogeogr 18:674-687 
Rödder D, Schmidtlein S, Veith M, Lötters S (2009) Alien invasive Slider turtle in unpredicted habitat: a matter of niche shift or predictors studied? PLoS ONE 4:e7843. doi:10.1371/journal.pone.0007843.

Rodríguez LO (1992) Structure et organization du peuplement d'anoures de Cocha Cashu, Parc nacional Manu, Amazonie péruvienne. Rev Ecol 47:151-197

Rodríguez LO, Duellman WE (1994) Guide to the frogs of the Iquitos region, Amazonian Peru. Spec Pap Mus Nat Hist Univ Kans 22:1-80 + plates 1-12

Santos JC, Coloma LA, Summers K, Caldwell JP, Ree R, Cannatella DC (2008) Amazonian amphibian diversity is primarily derived from late Miocene Andean lineages. PLoS Biol 7:e1000056

Schlüter A (2005) Amphibien an einem Stillgewässer in Peru. Chimaira, Frankfurt/Main

Swets K (1988) Measuring the accuracy of diagnostic systems. Science 240:1285-1293

Thompson JD, Higgins DG, Gibson TJ (1994) Clustal W: improving the sensitivity of the progressive multiple sequence alignment through sequence weighting, positions-specific gap penalties and weight matrix choice. Nucl Acid Res 22:4673-4680

Van der Meijden A, Boistel R, Gerlach J et al (2007) Molecular phylogenetic evidence for paraphyly of the genus Sooglossus, with the description of a new genus of Seychellean frogs. Biol J Linn Soc 91: 347-359

Vences M, Thomas M, Van der Meijden A et al (2005) Comparative performance of the 16S rRNA gene in DNA barcoding of amphibians. Front Zool 2:5

Warren DL, Glor RE, Turelli M (2008) Environmental niche equivalency versus conservatism: quantitative approaches to niche evolution. Evolution 62:2868-2883

Wiens JJ, Graham CH (2005) Niche conservatism: integrating evolution, ecology, and conservation biology. Annu Rev Ecol Syst 36:519-539

Wisz MS, Hijmans RJ, Peterson AT et al (2008) Effects of sample size on the performance of species distribution models. Divers Distrib 14:763-773 